\title{
Voltammetric Behavior of Tembotrione Using Silver/Amalgam Electrode
}

\author{
Milica Jović ${ }^{*}$ Dragan Manojlović, Dalibor Stanković, \\ Anđelija Milić, Milica Sentić, Goran Roglić \\ Faculty of Chemistry, University of Belgrade, Belgrade, Serbia \\ Email: ${ }^{*}$ milica_jovic@chem.bg.ac.rs
}

Received October 23, 2012; revised November 25, 2012; accepted December 3, 2012

\begin{abstract}
Tembotrione is herbicide which belongs to the triketone group of herbicides. It's registered as a selective, post-emergence herbicide developed for the control of a broad spectrum broadleaf and grassy weeds in corn. There is little information about tembotrione because of his short presence in the market. Due to its ever wider application, it is important to know the details of its chemical characteristics and redox processes, including biogeochemical transformation and migration after application to agricultural land, which could contribute to its efficient and safer application. In this paper we examined voltammetric behavior of tembotrione using Silver/Amalgam $(\mathrm{Ag} / \mathrm{Hg})$ electrode. For the investigation of electrochemical behavior we used the cyclic voltammetry technique, with conventional three-electrode cell and electrochemical workstation. During the experiment $\mathrm{pH}$ values of solution varieties while constant concentration of tembotrione was maintained. Cyclic voltammograms were recorded at $\mathrm{pH}$ values $6,8,10$ and 12 , at which tembotrione was electrochemically active. At this $\mathrm{pH}$ values two signals were observed. Optimum $\mathrm{pH}$ value, at which the current intensity was greatest, was 12 . Obtained results provide relevant information on the electrochemical behavior of tembotrione, which can serve as a basis for the development of electrochemical techniques for the removal and degradation of this pesticide in the environment.
\end{abstract}

Keywords: Pesticide; Tembotrione; Cyclic Voltammetry; Voltammetric Behavior; Silver/Amalgam Electrode

\section{Introduction}

Groundwater pollution with inorganic and organic pollutants is the serious problem in the supply of drinking water, and pesticides are one of the main organic pollutants $[1,2]$. Pesticides are widely used in agriculture and they have an important role, but the prevention of their negative effects requires a systematic control of content remaining in agricultural products, food, soil and water [3]. Today, traces of pesticides are increasingly present in the water, both surface and groundwater. The waste water concentrations of pesticides may be in $\mathrm{mg} / \mathrm{L}$, while surface water and groundwater contain $\mu \mathrm{g} / \mathrm{L}$ [1]. Mechanisms of pesticide reactions that lead to final stable products, which maybe pollutants themselves, are often not known in detail [4].

Key objective to modern pesticide research is to discover new products that control the widest possible range of weed species, as flexibly possible, and at low application rates. In addition, selective herbicides need to be safe to the target crop, and safe to the environment [5]. Triketone herbicides are new group of herbicides. Tem-

"Corresponding author. botrione is a member of this group. It is registered as a selective, post-emergence herbicide developed for the control of a broad spectrum of broadleaf and grassy weeds in corn including glyphosate, ALS-inhibitor and dicamba resistant weeds. It gives a very reliable crossspectrum weed control, including key grass species such as foxtails and woolly cupgrass [6]. Tembotrione is 2[2-chloro-4-(methylsulfonyl)-3-[(2,2,2-(trifluoroethoxy) methyl] benzoyl]-1,3-cyclohexanedione. The primary biochemical target site of tembotrione is the enzyme 4-hydroxyphenylpyruvate dioxygenase (HPPD), which catalyzes the formation of homogentisic acid, the aromatic precursor of plastoquinone and tocopherols (vita$\min$ E) [7]. Tembotrione appears to be stable to hydrolysis at environmental $\mathrm{pH}(\mathrm{pH}$ range 5 - 9). It has a high mobility in soil and the potential to leach into ground water [8]. The application rate of tembotrione is 0.092 $\mathrm{kg} / \mathrm{ha}$, followed 14 days later by a second treatment at the same application rate, if needed. Applications take place between crop emergence to the V8 (more than 8 visible leaves) developmental stage of corn. Tembotrione is broadcast applied using flat-fan nozzles that provide medium to coarse spray droplets [8]. Figure 1 gives the 
<smiles>CS(=O)(=O)c1ccc(C(=O)C2C(=O)CCCC2=O)c(Cl)c1COCC(F)(F)F</smiles>

Figure 1. Tembotrione 2-[2-chloro-4-(methylsulfonyl)-3-[(2,2, 2-(trifluoroethoxy) methyl]benzoyl]-1,3-cyclohexanedione.

chemical structure of the investigated pesticide.

There is a little information about electrochemical behavior of triketone pesticides. Due to wider tembotrione application, it is important to know details of its chemical characteristics and redox processes, including biogeochemical transformation and migration after application to agricultural land, which could contribute to its more efficient and safer application [9].

Mercury is good electrode material because of high hydrogen overvoltage (which enables to use a wide potential range for the measurements), atomically smooth surface and easy renewability of its surface. However, because of fears of mercury toxicity, there is a tendency to substitute mercury with other nontoxic materials. For that reason, new types of nontraditional electrode materials are being investigated. Solid amalgam electrodes are nontoxic, environmentally friendly electrodes. These electrodes exhibit high hydrogen overvoltage, in some cases comparable with that of Hanging Mercury Drop Electrode (HMDE). It can be used either as liquid mercury-free electrode after polishing of solid amalgam disk (p-AgSAE) or after modification of its surface by mercury meniscus (m-AgSAE). In this case it was p-AgSAE. The main advantages of solid amalgam electrodes are broad range of working potentials, simple electrochemical regeneration of the electrode surface, rapid pretreatment procedure, complete no toxicity of the solid amalgam phase and applicability even in mobile laboratories and in countries prohibiting the use of liquid mercury [10].

In the previous work, we described the electrochemical behavior of mesotrione, which also belong to triketone group, on $\mathrm{Ag} / \mathrm{Hg}$ electrode using cyclic voltammetry [11]. There is also report of voltammetric determination of mesotrione on HMDE [9], but no report related to the electrochemical behavior of tembotrione. This article aims to study electrochemical behavior of tembotrione which is base for electrochemical degradation, as a method for pesticide remediation, which is very important environmental topic.

\section{Methods}

\subsection{Reagents and Chemicals}

Tembotrione (95\% purity) was supplied from Institute for plants, Belgrade, Serbia. Silver electrode was supplied from Austin, USA. Methanol, potassium dihydrogen phosphate, sodium hydrogen phosphate, sodium hydrogen carbonate, sodium hydroxide, all of analytical grade purity, was obtained from Merck (Darmstadt, Germany).

As supporting electrolytes in voltammetric measurements different $\mathrm{pH}$ solutions were used: $\mathrm{KH}_{2} \mathrm{PO}_{4} / \mathrm{NaOH}$ buffer, $\mathrm{NaHCO}_{3} / \mathrm{NaOH}$ buffer and $\mathrm{Na}_{2} \mathrm{HPO}_{4} / \mathrm{NaOH}$ buffer.

\subsection{Apparatus}

All voltammetric measurements were carried out using a computerized voltammetric analyzer $\mathrm{CH}$ Instruments (Austin, USA) driven by voltammetric software $\mathrm{CHI}$ (Version 4.03). The three electrode system consisted of working electrode, reference electrode and auxiliary electrode. Working electrode was mercury buttoned silver electrode $(\mathrm{Ag} / \mathrm{Hg})$. Reference electrode was $\mathrm{Ag} / \mathrm{AgCl}$ (3M KCl) (CHI 221). Auxiliary electrode was platinum wire (CHI 111) (Figure 2).

For $\mathrm{pH}$ measurements, a $\mathrm{pH}$ meter, model 744, equipped with combined glass $\mathrm{pH}$ electrode and temperature sensor, all from Metrohm (Herisau, Switzerland) was used.

\subsection{Solutions and Electrode Preparation}

Tembotrione solution (concentration of $6 \times 10^{-3} \mathrm{~mol} / \mathrm{L}$ ) was prepared. First, $0.0053 \mathrm{~g}$ of tembotrione (95\% purity) was measured on analytical balance and dissolved in 2 $\mathrm{ml}$ of absolute methanol. Then, $2 \mathrm{ml}$ of supporting electrolyte was added, so the concentration of tembotrione was $3 \times 10^{-3} \mathrm{~mol} / \mathrm{L}$.

Silver/Amalgam electrode was prepared by a left to stand silver electrode in mercury for 24 hours. Silver is dissolved and silver amalgam (most probably crystalline $\mathrm{Ag}_{2} \mathrm{Hg}_{3}$ ) is formed. Thus obtained electrode has a lifetime of a month. Afterwards electrode needs to be regenerated. This is done by polishing it on powder of aluminum

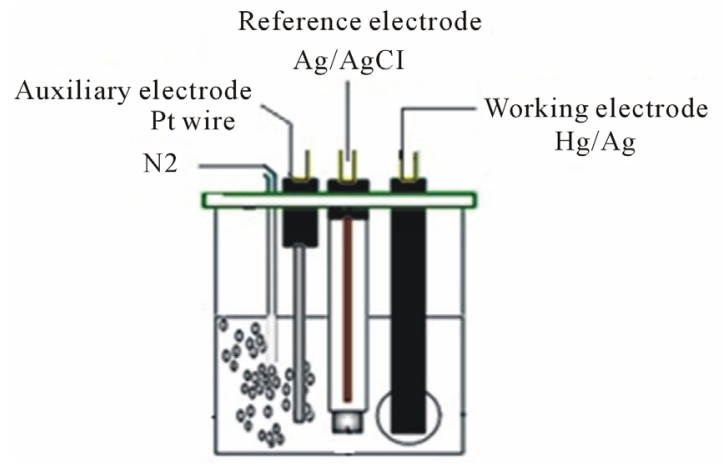

Figure 2. Electrochemical cell. 
$(0.05 \mu \mathrm{m})$, then rinsing with water and placing it in an ultrasonic bath. When this is done, electrode is placed in mercury for $24 \mathrm{~h}$.

\subsection{Procedures}

Cyclic voltammograms were recorded using $\mathrm{Ag} / \mathrm{Hg}$ electrode by gradually increasing scan rate. They were recorded at scan rates: $25 \mathrm{mV} \cdot \mathrm{s}^{-1}, 50 \mathrm{mV} \cdot \mathrm{s}^{-1}, 100 \mathrm{mV} \cdot \mathrm{s}^{-1}$, $200 \mathrm{mV} \cdot \mathrm{s}^{-1}, 300 \mathrm{mV} \cdot \mathrm{s}^{-1}, 400 \mathrm{mV} \cdot \mathrm{s}^{-1}, 500 \mathrm{mV} \cdot \mathrm{s}^{-1}, 600$ $\mathrm{mV} \cdot \mathrm{s}^{-1}$ and $700 \mathrm{mV} \cdot \mathrm{s}^{-1}$ for $\mathrm{pH}$ values $6,8,10$ and 12 . Different scan rates were selected to see if there is a shift of peaks with increasing scan speed. That is the first condition to be seen whether occurring electrochemical processes is reversible and whether the tested compound behaves electrochemically correctly. Molecule of tembotrione is large organic molecule with many functional groups which have different forms at different $\mathrm{pH}$, so it is expected that behavior would be different. Because of that it was necessary to examine his behavior at different $\mathrm{pH}$ values. Concentration of tembotrione in all experiments was $3 \times 10^{-3} \mathrm{~mol} / \mathrm{L}$.

\section{Results and Discussions}

\subsection{Electrochemical Behavior of Tembotrione Using $\mathrm{Ag} / \mathrm{Hg}$ Electrode}

Tembotrione contains several groups that may undergo electron transfer reactions and therefore the voltammetry is used for mechanistic and analytical studies [12,13]. For the investigation of electrochemical behavior of tembotrione cyclic voltammetry technique is used, with conventional three-electrode cell system and electrochemical workstation. On the basis of tembotrione structure, the reduction process probably involves reduction of two carbonyl groups on the cyclohexane ring, and third carbonyl group $[11,14]$. During the experiment $\mathrm{pH}$ values of aqueous solution variated while constant concentration of tembotrione was maintained. Cyclic voltammograms were recorded by gradually increasing scan rate.

Figure 3 shows the cyclovoltammogram of tembotrione at scan rates $25 \mathrm{mV} \cdot \mathrm{s}^{-1}, 50 \mathrm{mV} \cdot \mathrm{s}^{-1}, 100 \mathrm{mV} \cdot \mathrm{s}^{-1}$, $200 \mathrm{mV} \cdot \mathrm{s}^{-1}, 300 \mathrm{mV} \cdot \mathrm{s}^{-1}, 400 \mathrm{mV} \cdot \mathrm{s}^{-1}, 500 \mathrm{mV} \cdot \mathrm{s}^{-1}, 600$ $\mathrm{mV} \cdot \mathrm{s}^{-1}$ and $700 \mathrm{mV} \cdot \mathrm{s}^{-1}$, recorded on the instrument CHI 760. Supporting electrolyte was $0.1 \mathrm{M}$ phosphate buffer solution, $\mathrm{pH}=6$. Mercury buttoned silver electrode $(\mathrm{Ag} / \mathrm{Hg})$ was working electrode, $\mathrm{Ag} / \mathrm{AgCl}(3 \mathrm{M} \mathrm{KCl})$ was reference electrode, and platinum wire was auxiliary electrode.

On this cyclovoltammogram on potential (E) of -1.2068 $\mathrm{V}$ to the $\mathrm{Ag} / \mathrm{AgCl}$, well-defined spreading cathodic (reduction) peak was observed, which probably corresponds to the joint reduction of two carbonyl group on the cyclohexane ring. It is likely that the carbonyl groups on the cyclohexane have the same acidity at a given $\mathrm{pH}$, which is leading to the spread of peaks. On the potential (E) of $-1.4564 \mathrm{~V}$ another peak was observed. It probably corresponds to the reduction of the third carbonyl group $[11,14]$. The mechanism proposed is evaluated on the basis of the expected effects of structure $[15,16]$.

No anodic peak is observed in the reverse scan. This suggests that the reduction of tembotrione is irreversible at $\mathrm{Ag} / \mathrm{Hg}$ electrode at $\mathrm{pH} 6$.

Joint reduction of carbonyl group on the cyclohexane ring:<smiles>CCOCc1c(S(C)(=O)=O)ccc(C(=O)C2C(=O)CCCC2=O)c1Cl</smiles><smiles>CS(=O)(=O)c1ccc(C(=O)C2C(O)CCCC2O)c(Cl)c1COCC(F)(F)F</smiles>

Reduction of the third carbonyl group:<smiles>CS(=O)(=O)c1ccc(C(=O)C2C(=O)CCCC2=O)c(Cl)c1COCC(F)F</smiles><smiles>CS(=O)(=O)c1ccc(C(O)C2C(=O)CCCC2=O)c(Cl)c1COCC(F)(F)F</smiles> 


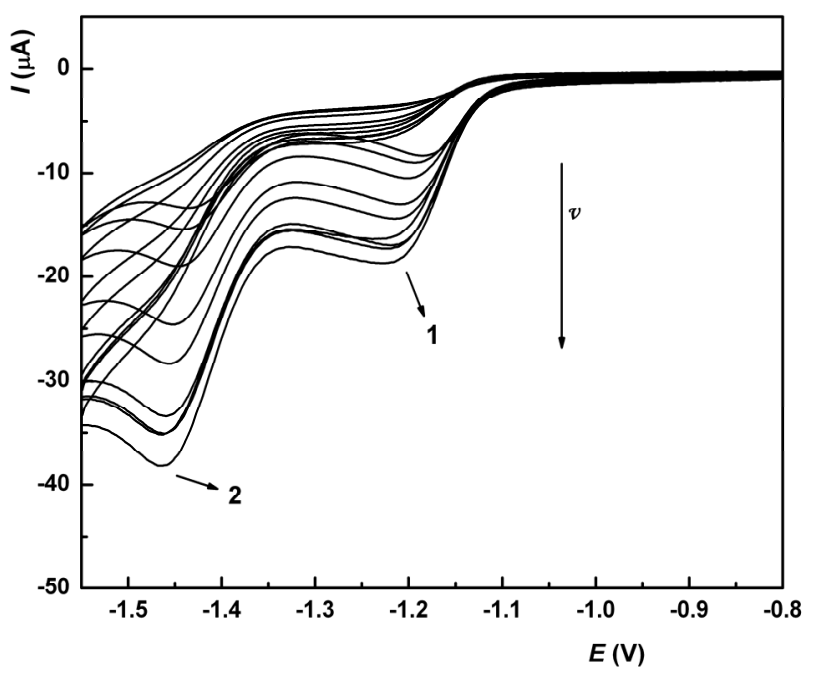

Figure 3. Cyclovoltammogram of tembotrione, $3 \times 10^{-3}$ $\mathrm{mol} / \mathrm{L}$, on $\mathrm{Ag} / \mathrm{Hg}$ electrode, $\mathrm{pH}=6$.

The dependence of the signal height with the square root of scan speed was shown at Figures 4 and $\mathbf{5}\left(\mathrm{R}_{1}=\right.$ 0.99901 and $R_{2}=0.99376$ ). In electrochemistry processes in which the current dependence of the square root is linear behave electrochemically properly, only diffusion current occurs, i.e. reaction taking place on the electrode is diffusion controlled. Voltammetric peaks came from diffusion current [17].

Figure 6 shows the cyclovoltammogram of tembotrione at scan rates $25 \mathrm{mV} \cdot \mathrm{s}^{-1}, 50 \mathrm{mV} \cdot \mathrm{s}^{-1}, 100 \mathrm{mV} \cdot \mathrm{s}^{-1}$, $200 \mathrm{mV} \cdot \mathrm{s}^{-1}, 300 \mathrm{mV} \cdot \mathrm{s}^{-1}, 400 \mathrm{mV} \cdot \mathrm{s}^{-1}, 500 \mathrm{mV} \cdot \mathrm{s}^{-1}, 600$ $\mathrm{mV} \cdot \mathrm{s}^{-1}$ and $700 \mathrm{mV} \cdot \mathrm{s}^{-1}$, recorded on the instrument $\mathrm{CHI}$ 760. Supporting electrolyte was $0.1 \mathrm{M}$ phosphate buffer solution, $\mathrm{pH}=8$. Mercury buttoned silver electrode $(\mathrm{Ag} / \mathrm{Hg})$ was working electrode, $\mathrm{Ag} / \mathrm{AgCl}(3 \mathrm{M} \mathrm{KCl})$ was reference electrode, and platinium wire was auxiliary electrode.

On the potential of $-1.2317 \mathrm{~V}$ cathode (reduction) peak was observed, which probably corresponds to the joint reduction of carbonyl group in positions 1 and 3 of cyclohexane ring. On the potential of $-1.4342 \mathrm{~V}$ was observed peak (signal 2), which probably comes from the reduction of the third carbonyl group. This peaks (signal 1 and 2) have lower intensity than the peaks at $\mathrm{pH}=6$, which indicates possible participation of chemical reactions (protonation). No anodic peak is observed in the reverse scan. This suggests that the reduction of tembotrione is irreversible at $\mathrm{Ag} / \mathrm{Hg}$ electrode at $\mathrm{pH} 8$.

Figure 7 (peak 1) shows the dependence of the signal height with the square root of scan speed (for comparing the correction factors). It indicates the quasireverse process and possible changes at diffusion layer. Nonlinearity of curve (correction factor $\mathrm{R}=0.92835$ ) indicates the participation of chemical reaction (protonation).

Figure 8 (peak 2) also show the dependence of the signal height with the square root of scan speed (for comparing the correction factors). It indicates that the

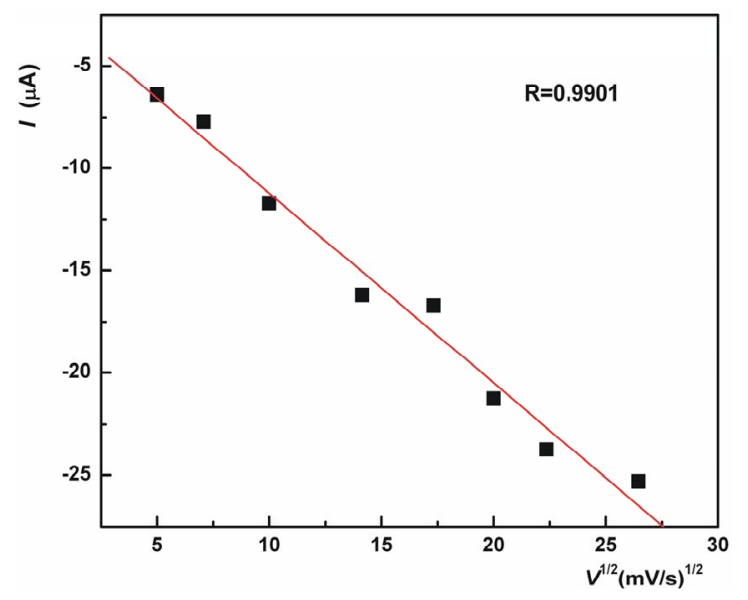

Figure 4. Current dependence on the square root of scan rate (for signal 1) on $\mathrm{Ag} / \mathrm{Hg}$ electrode, $\mathrm{pH}=6$.

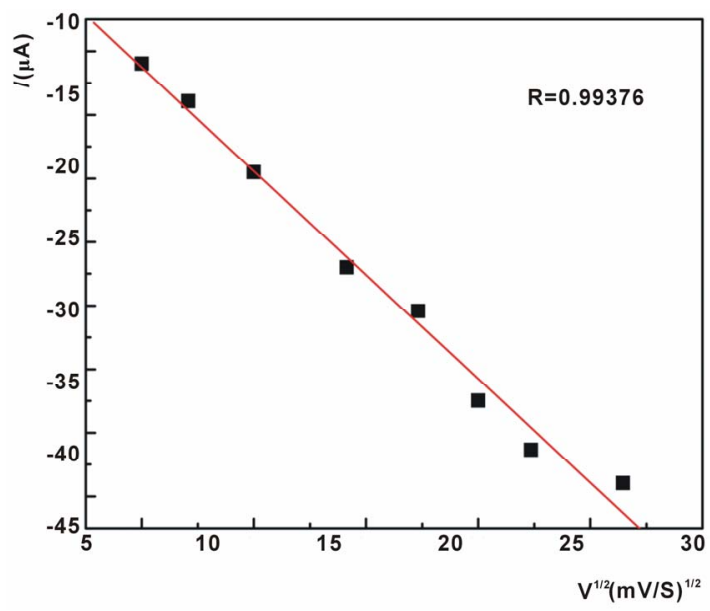

Figure 5. Current dependence on the square root of scan rate (for signal 2) on $\mathrm{Ag} / \mathrm{Hg}$ electrode, $\mathrm{pH}=6$.

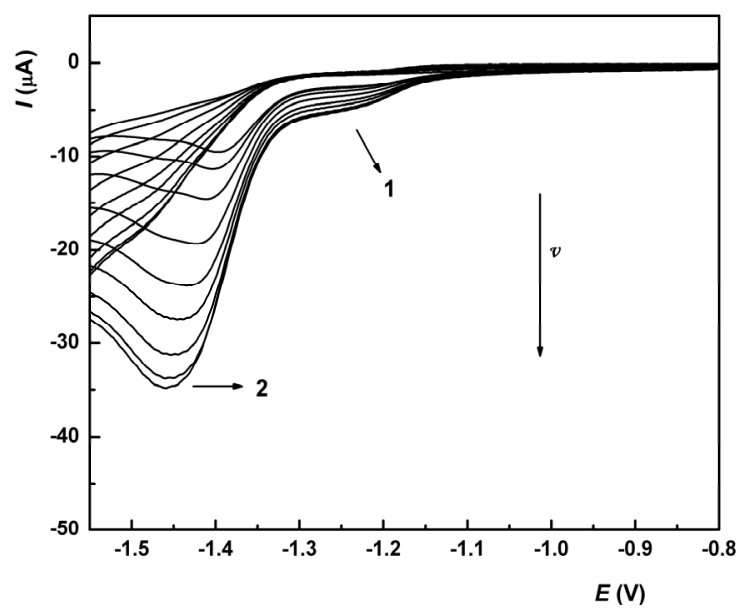

Figure 6. Cyclovoltammogram of tembotrione, $3 \times 10^{-3}$ $\mathrm{mol} / \mathrm{L}$, on $\mathrm{Ag} / \mathrm{Hg}$ electrode, $\mathrm{pH}=8$. 
electrochemical reactions are diffusion controlled, voltammetric peaks came from diffusion current [17].

Figure 9 shows the cyclovoltammogram of tembotrione at scan rates $25 \mathrm{mV} \cdot \mathrm{s}^{-1}, 50 \mathrm{mV} \cdot \mathrm{s}^{-1}, 100 \mathrm{mV} \cdot \mathrm{s}^{-1}$, $200 \mathrm{mV} \cdot \mathrm{s}^{-1}, 300 \mathrm{mV} \cdot \mathrm{s}^{-1}, 400 \mathrm{mV} \cdot \mathrm{s}^{-1}, 500 \mathrm{mV} \cdot \mathrm{s}^{-1}, 600$ $\mathrm{mV} \cdot \mathrm{s}^{-1}$ and $700 \mathrm{mV} \cdot \mathrm{s}^{-1}$, recorded on the instrument $\mathrm{CHI}$ 760. Supporting electrolyte was $0.1 \mathrm{M}$ carbonate buffer solution, $\mathrm{pH}=10$. Mercury buttoned silver electrode $(\mathrm{Ag} / \mathrm{Hg})$ was working electrode, $\mathrm{Ag} / \mathrm{AgCl}(3 \mathrm{M} \mathrm{KCl})$ was reference electrode, and platinum wire was auxiliary electrode.

On the potential of $-1.4330 \mathrm{~V}$ only one, well-defined, cathode (reduction) peak was observed. At $\mathrm{pH} 10$ there is only a reduction of third carbonyl group. Loss of signal 1 is maybe due to enolization of two symmetric carbonyl groups (have hydrogen of $\alpha$ type) in basic conditions. This is not happening at acidic $\mathrm{pH}$ values (6 and 8). Reverse peak wasn't observed. This suggests that the reduction of tembotrione is irreversible at $\mathrm{Ag} / \mathrm{Hg}$ electrode at

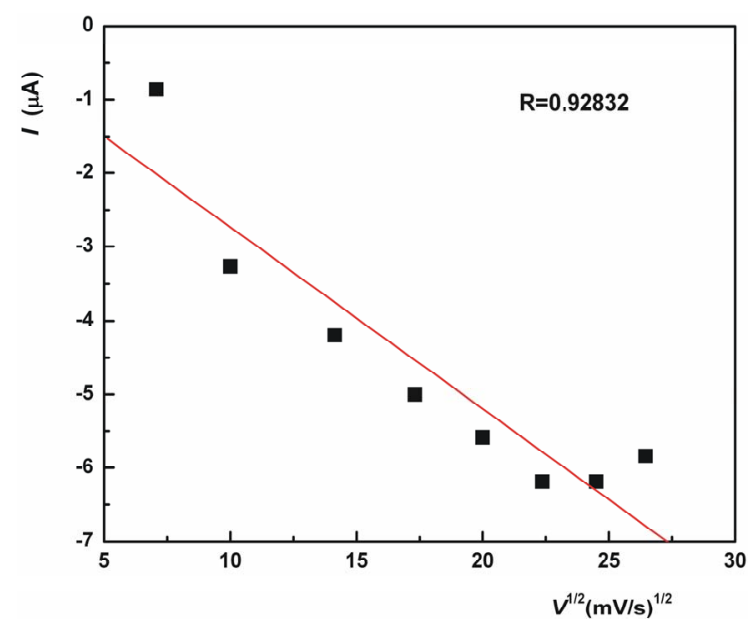

Figure 7. Current dependence on the square root of scan rate (for peak 1) on $\mathrm{Ag} / \mathrm{Hg}$ electrode, $\mathrm{pH}=8$.

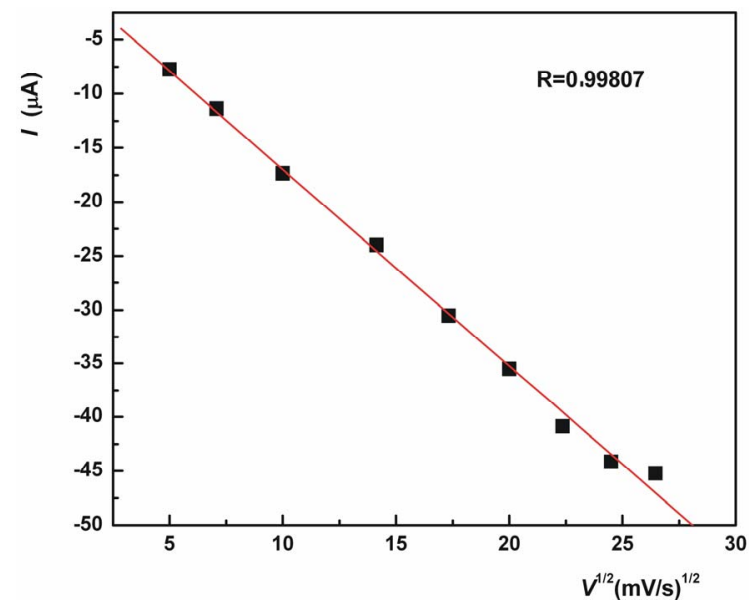

Figure 8. Current dependence on the square root of scan rate (for peak 2) on $\mathrm{Ag} / \mathrm{Hg}$ electrode, $\mathrm{pH}=8$.
$\mathrm{pH} 10$.

Figure 10 shows the dependence of the signal height with the square root of scan speed (for comparing the correction factors). It indicates that the electrochemical reactions are diffusion controlled, voltammetric peaks came from diffusion current [17].

Figure 11 shows the cyclovoltammogram of tembotrione at scan rates $25 \mathrm{mV} \cdot \mathrm{s}^{-1}, 50 \mathrm{mV} \cdot \mathrm{s}^{-1}, 100 \mathrm{mV} \cdot \mathrm{s}^{-1}$, $200 \mathrm{mV} \cdot \mathrm{s}^{-1}, 300 \mathrm{mV} \cdot \mathrm{s}^{-1}, 400 \mathrm{mV} \cdot \mathrm{s}^{-1}, 500 \mathrm{mV} \cdot \mathrm{s}^{-1}, 600$ $\mathrm{mV} \cdot \mathrm{s}^{-1}$ and $700 \mathrm{mV} \cdot \mathrm{s}^{-1}$. Supporting electrolyte was $0.1 \mathrm{M}$ phosphate buffer solution, $\mathrm{pH}=12$. Mercury buttoned silver electrode $(\mathrm{Ag} / \mathrm{Hg})$ was working electrode, $\mathrm{Ag} /$ $\mathrm{AgCl}(3 \mathrm{M} \mathrm{KCl})$ was reference electrode, and platinum wire was auxiliary electrode.

On the potential of $-1.4198 \mathrm{~V}$ only one, well-defined, cathode (reduction) peak was observed. Reverse peak wasn't observed. This suggests that the reduction of tembotrione is irreversible at $\mathrm{Ag} / \mathrm{Hg}$ electrode at $\mathrm{pH} 12$. Loss of signal 1 can be explained in the same way as for

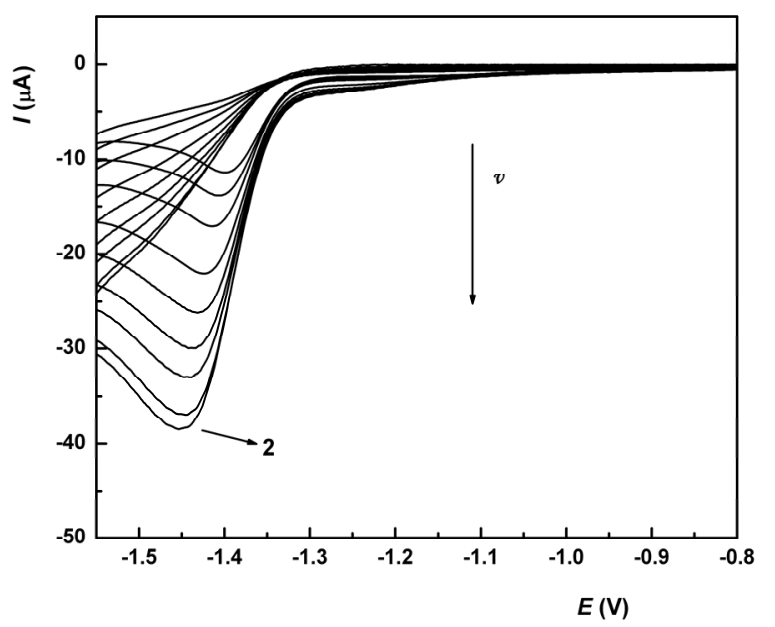

Figure 9. Cyclovoltammogram of tembotrione, $3 \times 10^{-3}$ $\mathrm{mol} / \mathrm{L}$, on $\mathrm{Ag} / \mathrm{Hg}$ electrode, $\mathrm{pH}=10$.

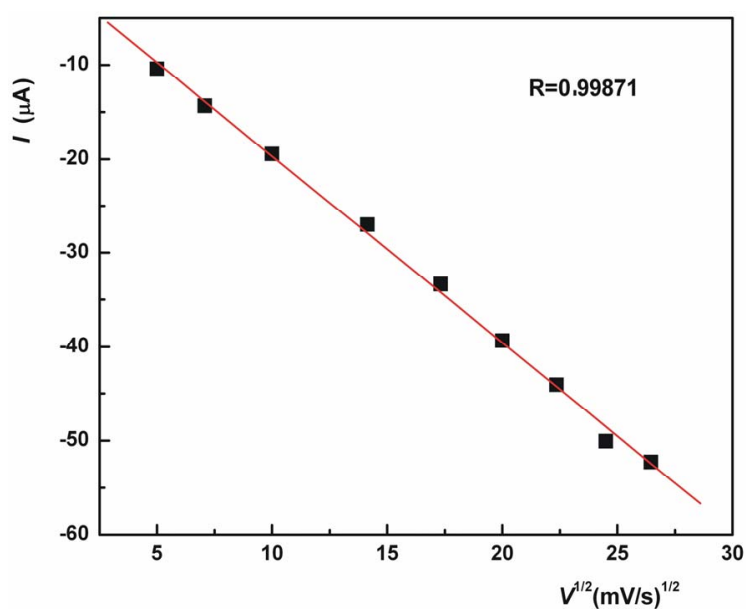

Figure 10. Current dependence on the square root of scan rate, on $\mathrm{Ag} / \mathrm{Hg}$ electrode, $\mathrm{pH}=\mathbf{1 0}$. 
$\mathrm{pH} 10$.

Figure 12 shows the dependence of the signal height with the square root of scan speed (for comparing the correction factors). It indicates that the electrochemical reactions are diffusion controlled, voltammetric peaks came from diffusion current [17].

Figure 13 shows the dependence of potential (E) of the solution $\mathrm{pH}$, for signal 2. It indicates that the peak position changes with change of $\mathrm{pH}$ value. In this case potential increased with increasing $\mathrm{pH}$. Based on this, can be concluded that change of position for signal 2 probably comes from participation of both, chemical and electrochemical reaction. Signal 1 at $\mathrm{pH} 6$ have potential of $-1.2068 \mathrm{~V}$, at $\mathrm{pH} 8,-1.2317 \mathrm{~V}$.

Table 1 shows values of current 1) and $\mathrm{pH}$, for peak 2 . It indicates that the peak intensity change with $\mathrm{pH}$. This change in signal intensity most likely is due to the participation of chemical and electrochemical reaction. From the table we can see optimum $\mathrm{pH}$ value at which the

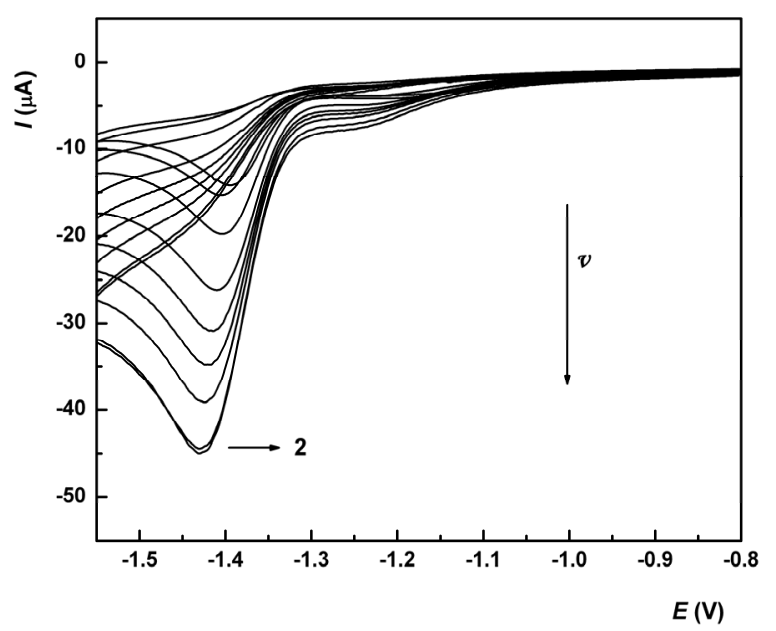

Figure 11. Cyclovoltammogram of tembotrione, $3 \times 10^{-3}$ $\mathrm{mol} / \mathrm{L}$, on $\mathrm{Ag} / \mathrm{Hg}$ electrode, $\mathrm{pH}=12$.

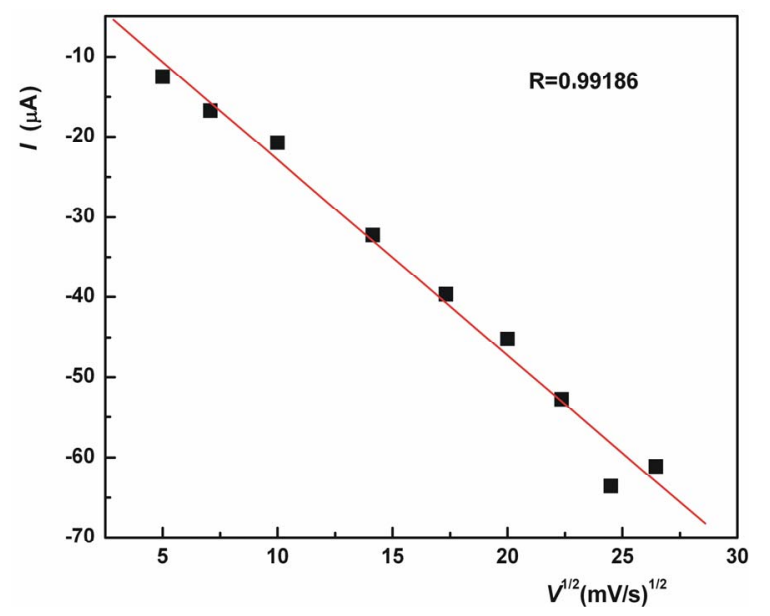

Figure 12. Current dependence on the square root of scan rate, on $\mathrm{Ag} / \mathrm{Hg}$ electrode, $\mathrm{pH}=12$.

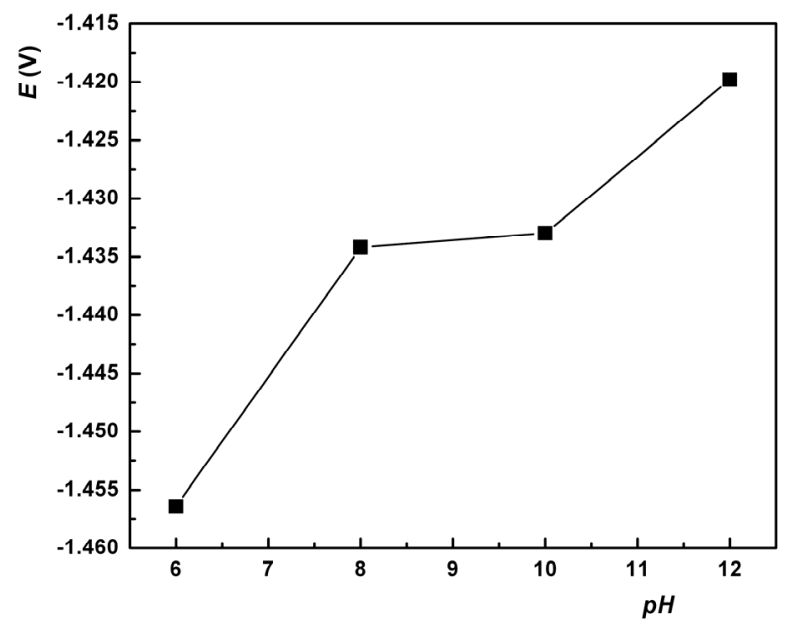

Figure 13. Potential dependence of $\mathrm{pH}$ for signal 2.

Table 1. Current dependence of pH for peak 2 .

\begin{tabular}{cc}
\hline $\mathrm{pH}$ & $\mathrm{I}, \mu \mathrm{A}$ \\
\hline 6 & 20 \\
8 & 17 \\
10 & 20 \\
12 & 21 \\
\hline
\end{tabular}

current intensity is greatest. The optimum $\mathrm{pH}$ value is 12 .

\section{Conclusions}

Based on this results it was found that $\mathrm{Ag} / \mathrm{Hg}$ (Silver/ Amalgam) electrode can be used for the determination of electrochemical behavior of tembotrione. Tembotrione was electrochemically active at investigated $\mathrm{pH}(6,8,10$ and 12). At $\mathrm{pH}$ values 6 and 8 two signals were observed (joint reduction of carbonyl groups on cyclohexane ring and reduction of third carbonyl group), while at $\mathrm{pH}$ values 10 and 12 only one signal was observed (reduction of third carbonyl group). The maximum current value was obtained at $\mathrm{pH} 12$.

According to the classical theory of reversibility it is a typical irreversible system (absence of anodic oxidation signal). Absence of anodic peak should be investigated with the $\mathrm{Ag} / \mathrm{Hg}$ microelectrode at higher polarization speeds. Dependence of peak intensity on the scan rate indicates the diffusion controlled process.

Obtained results provide relevant information on the electrochemical behavior of tembotrione, which can serve as a basis for the development of electrochemical techniques for the removal and degradation of this pesticide in the environment. Working electrode $(\mathrm{Ag} / \mathrm{Hg})$ is solid state electrode and there are no environmental problems, unlike those with liquid electrodes (HMDE) [9]. 


\section{Acknowledgements}

This paper is supported by Serbian Ministry of Education and Science, project number 172030.

\section{REFERENCES}

[1] S. Goldstein, D. Meyerstein and G. Czapski, "The Fenton Reagents," Free Radical Biology and Medicine, Vol. 15, No. 4, 1993, pp. 435-445. doi:10.1016/0891-5849(93)90043-T

[2] H. Roßknecht, H. Hetzenauer and T. A. Ternes, "Arzneimittel im Bodensee?" Nachrichten aus der Chemie, Vol. 49, No. 2, 2001, pp. 145-149. doi:10.1002/nadc. 20010490210

[3] P. Manisankar, S. Viswanathan, A. M. Pusphalatha and C. Rani, "Electrochemical Studies and Square Wave Stripping Voltammetry of Five Common Pesticides on Poly 3,4-Ethylenedioxythiophene Modified Wall-Jet Electrode," Analytica Chimica Acta, Vol. 528, No. 2, 2005, pp. 157163. doi:10.1016/j.aca.2004.08.027

[4] L. Pospíšil, R. Sokolova, M. P. Colombini, S. Giannarelli and R. Fuoco, "Electrochemical Properties of Three Dicarboximide-Type Pesticides: Vinclozoline, Iprodione and Procymidone," Journal of Electroanalytical Chemistry, Vol. 472, No. 1, 1999, pp. 33-41. doi:10.1016/S0022-0728(99)00256-9

[5] A. J. F. Edmunds, W. Kramer and U. Schirmer, "Modern Crop Protection Compounds," Wiley-VCH Verlag GmbH \& Co KGaA, Weinheim, 2007.

[6] A. van Almsick, J. Benet-Buchholz, B. Olenik and L. Willms, "Tembotrione, a New Exceptionally Safe CrossSpectrum Herbicide for Corn Production," Bayer CropScience Journal, Vol. 62, No. 1, 2009, pp. 5-16.

[7] "Pesticide Fact Sheet," United States Environmental Protection Agency, Washington DC, 2007.

[8] W. Schulte and H. Köcher, "Tembotrione and Combination Partner Isoxadifen-Ethyl-Mode of Herbicidal Action," Bayer CropScience Journal, Vol. 62, No. 1, 2009 , pp. 35-52.

[9] G. Erdogdu and S. Titretir, "Voltammetric Determination of Mesotrione at Hanging Mercury Drop Electrode," Journal of Analytical Chemistry, Vol. 62, No. 8, 2007, pp. 777-780. doi:10.1134/S106193480708014X

[10] J. Fischer, J. Barek, B. Yosypchuk and T. Navratil, "Voltammetric Determination of Trace Amounts of 2-Methyl4,6-Dinitrophenol at a Silver Solid Amalgam Electrode," Electroanalysis, Vol. 18, No. 2, 2005, pp. 127-130. doi:10.1002/elan.200503366

[11] M. Jović, D. Manojlović, D. Stanković, A. Milić, M. Sentić and G. Roglić, "Volta Metric Behavior of Mesotrione Using Silver/Amalgam Electrode," International Journal of Environmental Research, 2012. (In press)

[12] M. Trojanowicz, "Determination of Pesticides Using Electrochemical Enzymatic Biosensors," Electroanalysis, Vol. 14, No. 19-20, 2002, pp. 1311-1328. doi:10.1002/1521-4109(200211)14:19/20<1311::AID-EL AN1311>3.0.CO;2-7

[13] C. Aprea, C. Colosio, T. Mammone, C. Minoia and M. Maroni, "Biological Monitoring of Pesticide Exposure: A Review of Analytical Methods," Journal of Chromatography $B$, Vol. 769, No. 2, 2002, pp. 191-219. doi:10.1016/S1570-0232(02)00044-2

[14] M. Delamar, G. Désarmot, O. Fagebaume, R. Hitmi, J. Pinson and J.-M. Savéant, "Modification of Carbon Fiber Surfaces by Electrochemical Reduction of Aryl Diazonium Salts: Application to Carbon Epoxy Composites," Carbon, Vol. 35, No. 6, 1997, pp. 801-807. doi:10.1016/S0008-6223(97)00010-9

[15] P. J. Elving and J. T. Leone, "Mechanism of the Electrochemical Reduction of Phenyl Ketones," Journal of the American Chemical Society, Vol. 80, No. 5, 1958, pp. 1021-1029. doi:10.1021/ja01538a002

[16] A. Adenier, M.-C. Bernard, M. M. Chehimi, E. CabetDeliry, B. Desbat, O. Fagebaume, J. Pinson and F. Podvorica, "Covalent Modification of Iron Surfaces by Electrochemical Reduction of Aryldiazonium Salts," Journal of the American Chemical Society, Vol. 123, No. 19, 2001, pp. 4541-4549. doi:10.1021/ja003276f

[17] A. J. Bard and L. R. Faulkner, "Electrochemical Methods: Fundamentals and Applications," John Wiley and Sons, Inc., New York, 2001. 